\title{
The effect of nucleic acids on growth, ureagenesis and nitrogen excretion of gilthead sea bream Sparus aurata juveniles
}

\author{
A. Oliva-Teles ${ }^{a, b, ~}{ }^{*}$, M.J. Guedes ${ }^{a}$, C. Vachot ${ }^{c}$ and S.J. Kaushik ${ }^{c}$
}

\author{
a Departamento de Zoologia e Antropologia, Faculdade de Ciências, Universidade do Porto, Praça Gomes \\ Teixeira, 4099-002 Porto, Portugal \\ ${ }^{b}$ CIIMAR-Centro Interdisciplinar de Investigação Marinha e Ambiental, Rua dos Bragas 289, 4050-123 Porto, \\ Portugal \\ ${ }^{c}$ Fish Nutrition Laboratory, UMR NuAGe, INRA-IFREMER-Univ. Bordeaux I, Fish 10 Nutrition Lab, Station \\ d'Hydrobiologie, BP 3, 64310 Saint Pée-sur-Nivelle, France
}

\author{
*: Corresponding author : A. Oliva-Teles, Tel.: +351 223401507; fax: +351 223401511, email address \\ : $\underline{\text { aoteles@fc.up.pt }}$
}

\begin{abstract}
:
The aim of this trial was to evaluate the effect of dietary nucleic acids on ureagenesis and nitrogen balance in gilthead sea bream juveniles. For that purpose, 5 isonitrogenous $(7.25 \% \mathrm{~N})$ diets were formulated based on fish meal as protein source (FM-control diet) and to partially replace the fish meal nitrogen with two levels of nucleic acids (diets RNA1 and RNA2) or brewers yeast (diets BY1 and BY2). Each diet was fed for 10 weeks, to apparent visual satiety, to triplicate groups of 50 fish each with an average body weight of $12.7 \mathrm{~g}$.

Inclusion of nucleic acid $\mathrm{N}$ either as brewers yeast or RNA led to significant improvement of feed intake and growth, except for fish fed diet RNA2. There were no differences in final weight between groups fed the yeast- and the RNA-containing diets. Although there was an improvement of growth rate of fish fed the RNA or yeast containing diets, dietary nucleic acid supplementation did not have a clear $\mathrm{N}$ sparing effect. At the end of the trial there were no significant differences in whole body composition among groups, except for the lipid content which was significantly higher in fish fed the Y2 diet.

Hepatic glutamate dehydrogenase activity levels did not differ among groups. Ornithine carbamyl transferase activities were very low in all groups, but appear to be induced by high levels of dietary RNA. Fish fed the yeast diets exhibited the highest arginase activity of all groups. No increase of uricase activities was observed in fish fed the RNA supplemented diets.

Ammonia and urea excretion of fish fed the RNA-including diets was higher or significantly higher than in the other groups. Plasma urea levels were higher in fish fed the RNA diets than in the other groups confirming excretion data in that dietary nucleic acid influenced urea excretion through uricolysis.

In conclusion, substitution of $\mathrm{N}$ supplied by fish meal by that supplied by brewers yeast had a positive effect on growth performance of sea bream, while dietary nucleic acid supplementation did not have a clear N sparing effect. At a dietary level of $11.5 \%$ of RNA extract, there was no improvement of fish performance compared to the control, possibly due to an insufficient capacity of fish to degrade high levels of nucleic acid. Data on excretion and plasma metabolites strongly suggest that purinolysis contributes also to ureogenesis in gilthead sea bream.
\end{abstract}

Keywords: RNA; Brewers yeast; Ureagenesis; N accretion; Sea bream 


\section{INTRODUCTION}

3

4

Fish meal is an expensive protein source and efforts are being devoted to the reduction of this commodity in aquaculture feeds (Watanabe, 2002). Among alternative protein sources, single cell proteins (SCP) such as yeasts have good potential, due to its high nitrogen content, which may allow high levels of fish meal replacement in the diets (Tacon and Jackson, 1985; Tacon, 1994; Anupama and Ravindra, 2000).

Several studies have shown that yeasts can successfully replace part of dietary fish meal in different fish species (Matty and Smith, 1978; Alliot et al., 1979; Mahnken et al., 1980; Rumsey et al., 1991a; Metailler and Huelvan, 1993; Takii et al., 1999; OlivaTeles and Gonçalves, 2001; Olvera-Novoa et al., 2002; Fournier et al., 2002). Compared to fish meal, yeasts are deficient in some essential amino acids, therefore it is not surprising that high dietary inclusion levels of yeast usually lead to a depression of fish performance (Nose, 1974; Atack and Matty, 1979; Spinelli et al., 1979; Beck et al, 1979; Mahnken et al., 1980; De la Huiguera et al., 1981; Rumsey et al., 1991 a). In some studies, supplementation of yeast-containing diets with limiting amino acids improved fish performance (Nose, 1974; Bergstrom, 1979; Spinelli et al., 1979; Murray and Marchant, 1986), although in other studies such a supplementation did not provide any benefits (Mahnken et al., 1980; Gonçalves and Oliva-Teles, 1999).

Besides being an interesting alternative protein source to fish meal, yeasts are also valuable as having immunostimulant (Anderson, 1992; Gannan and Schrock, 1999; Sakai, 1999) and probiotic (Gatesoupe, 1999; Irianto and Austin, 2002) properties, improving growth, health, disease resistance and immune system.

One limitation to the use of high levels of yeast in fish diets is its relatively high non protein nitrogen content, in the form of nucleic acids. These are present mostly as RNA and represent approximately 13\% - 23\% of total nitrogen (Schulz and Oslage, 1976; Anupama and Ravindra, 2000). In humans, excessive intake of nucleic acid is toxic due to the limited capacity of urinary excretion of the uric acid formed from nucleotide catabolism (Schulz and Oslage, 1976). In the case of farmed animals, high levels of 
1 dietary nucleic acids elevate plasma uric acid and produce toxicological effects and

2 disturbance in metabolism (Rumse y et al., 1991a). This, however, do not seem to occur

3 in fish as they have a very active liver uricase (Kinsella et al., 1985; Rumsey et al., 4 1991a)

Nucleotides can be synthesized endogenously and thus are not considered essential nutrients (Carver, 1999). But dietary nucleotides have beneficial effects, as they positively affect the immune system, hepatic function, lipid metabolism, disease

9 resistance, development of small intestine and growth (Carver and Walker, 1995; Cosgrove, 1998, Carver, 1999; Burrells et al., 2001a; Low et al., 2003; Li et al., 2004).

It is also considered that under conditions of limited nucleotide intake or rapid growth, dietary nucleic acids may have a protein sparing effect, as it limits the de novo synthesis of these molecules from its amino acid precursors (Carver, 1999). Indeed, in fish, incorporation of RNA extract in the diets improved performance of rainbow trout when fed a purified diet (Rumsey et al., 1992). However, a negative effect or no beneficial effect was noticed in different fish species fed practical diets supplemented with RNA extracts (Tacon and Cooke, 1980; Fournier et al., 2002; Peres and OlivaTeles, 2003). On the other hand, under conditions of management and environmental stressors (vaccination, grading, salt water transfer, etc.) associated to farming, a beneficial effect of dietary nucleotide supplementation on growth rate was observed in Atlantic salmon by Burrells et al. (2001b).

The objectives of this trial were to evaluate the effect of dietary nucleic acid (RNA) and yeast supplementation on growth, feed utilization, ureagenesis and nitrogen excretion of sea bream. The principle was to formulate isonitrogenous diets based on fish meal as protein source and to partially replace the fish meal nitrogen with two levels of nucleic acids and yeast. The work consisted of analysis of growth rate and $\mathrm{N}$ accretion, measurement of daily ammonia $\mathrm{N}$ and urea- $\mathrm{N}$ excretion, analysis of plasma metabolites and assays of hepatic enzyme activities involved in amino acid oxidation: glutamate dehydrogenase (GDH); urea cycle: ornithine carbamyltransferase (OCT) and arginase; and an end enzyme of purine degradation: uricase. 


\section{MATERIAL \& METHODS}

2 Experimental diets

3

4 5

Five practical diets were formulated and prepared to contain a constant level of $\mathrm{N}$ (7.25\% DM). A first diet in which proteins were supplied essentially by fish meal was used as reference (diet FM). Four other diets were formulated in which fish meal and wheat were partly replaced by two levels of a ribonucleic acid extracted from yeast (diets RNA1 and RNA2) and two levels of dried brewer's yeast (diets BY1 and BY2). After homogenisation of all the raw materials, diets were pelleted, dried for $10 \mathrm{~min}$ at $80^{\circ} \mathrm{C}$ and $10 \mathrm{~min}$ at room temperature in a ventilated drier and sieved in two diameters: 2 and $3 \mathrm{~mm}$. The ingredient composition, analysed proximate composition and nucleic acid nitrogen content (NAN) of the experimental diets are shown in table1.

Feeding trial

The feeding trial was conducted at the Marine Zoology Station of Faculty of Sciences of University of Porto. The experimental facilities consisted of an indoor partial recirculating sea water system provided with 15 cylindrical tanks of $250 \mathrm{l}$ of water capacity. Water temperature was maintained at $20{ }^{\circ} \mathrm{C}$ and salinity averaged 32.6 $\%$.

Juvenile gilthead sea bream (Sparus aurata) were obtained from a commercial fish farm and were stabulated in quarantine tanks at the Marine Station, to recover from transport and to adapt to the new environmental conditions and experimental facilities. Thereafter 15 groups of 50 fish with an average body weight of 12.7 g were established and to triplicate groups of these fish was randomly assigned each experimental diet. The trial lasted 10 weeks and the fish were fed by hand twice a day (at 10 and 16 h), to apparent visual satiety, 6 days a week. During the trial the fish were counted and bulk weighed every two weeks, after applying a mild anaesthesia (ethylene glycol monophenyl ether 1:2500). The fish were unfed the day before weighing, and feed distributed during the period was registered at the weighing days.

Whole body composition was determined on a pooled sample of ten fish from the initial stock population, and pools of six fish per each tank at the end of the trial. Specimens for whole body analysis were sacrificed by an overdose of anaesthetic (ethylene glycol monophenyl ether) and were kept frozen until analysis. 
2 Nitrogen excretion

3 Measurements of total ammonia and urea-nitrogen excretions were performed 4 during the growth trial, at week 6, for 2 consecutive days in each tank. For that purpose, 5 water flow rate in the tanks was reduced to 2-3 1/min the day before and during the 6 sampling days. Water samples were collected in the outlet of each tank at $0,2,4,6,8$, 7 10, 12, 18 and 24h after the first meal. Water collected in the outlet of a tank without 8 fish was used as a blank.

\section{Blood and liver sampling}

Livers and blood samples were taken from randomly selected fish 6-h after feeding in order to measure plasma levels of $\mathrm{N}$ catabolites (total ammonia, urea) and the activity of selected enzymes involved in purine catabolism (uricase, EC 1.7.3.3), ammoniagenesis (glutamate dehydogenase GDH, EC 1.4.1.2), arginine degradation (arginase ARG, EC 3.5.3.1) and ornithine-urea cycle-OUC (ornithine carbamoyl 16 transferase OCT, EC 2.1.3.3).

At the end of the growth trial, sea bream continued to be fed twice a day for a few more days. Then, five fish per tank were killed by a blow on the head. Livers were rapidly excised, weighed and deed frozen until analyzed. Blood samples $(0.5 \mathrm{ml})$ were recovered from caudal vessels into heparinized syringes. Plasma was recovered after centrifugation at $3000 \mathrm{~g}$ for ten minutes and stored at $-20^{\circ} \mathrm{C}$ until analyzed.

Analytical methods

The diets and pooled fish sampled for determining whole body composition were ground and analyzed according to AOAC (1980) methods. The nucleic acid-N content of the diets and main ingredients was determined according to Imafidon and 27 Sosulsky (1990).

Ammonia and urea in plasma were determined spectrophotometrically using diagnostic kits (Sigma 171a and 535, respectively). Water ammonia was measured by the indophenol method (Koroleff, 1983a) and urea by the urea-diacetylmonoxime method, according to (Koroleff, 1983b). 
Liver ornithine-urea cycle enzymes (OCT, arginase) activity were measured

2 using a modified procedure of Brown and Cohen (1959), glutamate dehydrogenase

3 activity was measured according to a modified procedure of Bergmeyer (1974) and

4 uricase activity by a modified procedure of Kinsella et al. (1985) and Cleere et al.

5 (1976). The protein content of the extracts was determined according to Bradford 6 (1976).

\section{Statistical analyses}

Statistical analysis of the data was done by one-way analysis of variance using a Statgraphics Plus for Windows version 4 software package. Significant differences among means were determined by the Tukey HSD test. Statistical comparison among means was made at a significance level of 0.05 .

\section{RESULTS}

\section{Growth performance and feed efficiency}

Mortality was negligible throughout the trial (3 fish out of 750 being stocked). No evidence of outward pathological signs was noted in fish fed the different diets.

Data on growth performance and feed utilization is presented in table 2. During the trial, all diets were well accepted by fish. Voluntary feed intake was significantly lower in fish fed the control diet and those fed diet RNA2 than in groups fed the other diets. Despite these differences in feed intake, no statistical difference due to dietary treatments was found in feed efficiency.

Final weight and growth rate of fish fed the control diet and those fed diet RNA2 was significantly lower than in the other groups. There was a significantly lower growth rate in fish fed the diet RNA2 as compared to those fed diet RNA1

Protein efficiency ratio in fish fed the control diet was significantly higher than in the other groups. Also, protein efficiency ratio of fish fed the RNA diets was

28 significantly higher than in fish fed the yeast diets. However, there were no significant differences in $\mathrm{N}$ gain among groups, both expressed per unit of weight gain or as per cent of $\mathrm{N}$ intake. 
2 Body composition

3 Data on the initial and final whole body composition are reported in table 3. At 4 the end of the trial there were no significant differences in whole body composition 5 among groups, except for the lipid content of sea bream fed BY2 diet, which was

6 significantly higher than in the other groups. Although hepatosomatic indices were 7 higher in fish fed the RNA extract containing diets than in the other groups, differences 8 among groups were not statistically significant.

10 Enzyme activities

11 Activities of selected enzymes of nitrogen metabolism are presented in table 4. 12 Glutamate dehydrogenase activities were significantly lower in fish fed diets BY2 and 13 RNA1 than in the other groups. Ornithine carbamoyl transferase activities were very 14 low in all groups, but were higher in fish fed diets containing nucleic acid nitrogen than 15 in the fish meal diet fed group. Fish fed the yeast diets exhibited a significantly higher 16 arginase activity than in the other groups, while group fed diet RNA2 showed the lowest 17 arginase activity. No increases of uricase activities were observed in fish fed RNA 18 supplemented diets.

\section{Plasma metabolites}

Plasma ammonia significantly increased with the increase of yeast or nucleic 22 acid in the diets, and was significantly higher in fish fed diet RNA2 than in the other groups (table 4). Plasma urea was significantly higher in fish fed the RNA diets, and significantly increased with the nucleic acid inclusion in the diets (table 4).

\section{Urea and ammonia excretion}

As shown in table 5, ammonia excretion rates tended to be higher in fish fed the experimental diets than in the control. In fish fed the RNA diets, ammonia excretion was significantly higher than in the control, both expressed per unit of body weight or as per cent of $\mathrm{N}$ intake. Also, ammonia excretion tended to be higher in fish fed the RNA 
1 diets than the brewer's yeast containing diets, and this difference was statistically

2 significant if expressed as per cent of $\mathrm{N}$ intake.

3

Urea- $\mathrm{N}$ excretion (absolute values or in percentage of $\mathrm{N}$ intake) was significantly higher in fish fed RNA2 diet relatively to the other diets.

Total N (ammonia + urea) excretion was significantly higher in fish fed RNA diets than in the control. In fish fed the BY diets total $\mathrm{N}$ excretion tended to be higher than in the control group, although differences among groups were not significant.

Globally, urea N excretion represented 13 - $18 \%$ of total ammonia plus urea excretion, and was significantly higher in fish fed the control and RNA2 diets than in the other groups.

\section{DISCUSSION}

\section{Growth and feed utilization}

In this trial, growth of gilthead sea bream fed the brewers yeast containing diets was significantly higher than that of fish fed the fish meal-based control diet, while there were no significant differences in feed efficiency. This is the first time that brewers yeast was evaluated as a fish meal substitute in the diets for gilthead sea bream. Brewers yeast was already assayed as an alternative protein source in a variety of fish species with good results. For instance, in rainbow trout, growth and feed efficiency was significantly higher than in a casein-based control diet at a dietary incorporation level of 25\% (Rumsey et al., 1991a). However, performance was impaired at higher dietary levels apparently due to unpalatability of this protein source to rainbow trout (Rumsey et al., 1991a). Disruption of the yeast cell wall increased the nutritional value of yeasts to rainbow trout, due to increase of nitrogen and energy digestibility of the cell components (Rumsey et al., 1991b). In lake trout, growth and feed conversion of fish fed diets with $50 \%$ yeast protein (representing a dietary incorporation of $32.4 \%$ ) replacing a casein:gelatine mixture was lower than the control; however, diets including yeast with disrupted cell wall performed similarly to controls (Rumsey et al. (1990). This indicates that disruption of cell walls increases the availability of intracellular nitrogen, suggesting that this treatment may allow a higher inclusion level of yeast in fish diets 
In a comparative study by Fournier et al. (2002) brewers yeast was incorporated

2 in the diets for rainbow trout and turbot at levels up to $17.4 \%$ and $22.5 \%$, respectively, 3 without significantly affecting growth rate or feed efficiency. Also, in red sea bream, 4 growth showed a significant positive trend with the inclusion of up to $34 \%$ brewers 5 yeast in the diet, replacing brown fish meal, while feed efficiency was not significantly 6 affected (Takii et al., 1999).

In European sea bass, brewers yeast was able to replace 50\% of fish meal protein 8 (representing a dietary incorporation of almost 55\% yeast) with equivalent growth rates, 9 while feed efficiency significantly improved with dietary brewers yeast inclusion up to 33 \% (Oliva-Teles and Gonçalves, 2001). In an early study also in European sea bass, both growth and feed efficiency were significantly lower than in the fish meal-based control in fish fed diets including $10 \%$ of brewers yeast, but not in diets including lactic or baker yeasts (Metailler and Huelvan, 1993). In this last trial fish received a restricted ration and this may explain the negative results observed. Indeed, both in the present trial as well as in the other above mentioned trials, fish were fed to satiety and feed intake was higher (except in the study of Fournier et al., 2002) in fish fed the brewers yeast diets than in the controls. Even though, feed efficiency was not negatively affected due to this higher feed intake in the brewers yeast groups.

In the present study, inclusion of about $6 \%$ of RNA extract led to significantly better growth of fish, but a higher inclusion level did not lead to any beneficial effect. As with the BY diets, voluntary feed intake of fish fed the RNA diets was significantly higher but feed efficiency was similar to that observed with the control diet.

In rainbow trout, fish fed increasing levels (0.6\%-4.1\%) of RNA extract, corresponding to a dietary brewers yeast level of $7.5 \%$ to $50 \%$, also showed an incremental increase in growth and feed intake while feed efficiency significantly increased (Rumsey et al., 1992). These authors also showed that composition of nucleotides is important, as free-adenine acted as a potent inhibitor of feed intake and growth, while the remaining purine bases had no negative effects on these parameters. 29 In another study with rainbow trout, no deleterious effect on growth and feed conversion was observed in fish fed RNA extract of bacterial origin up to a dietary inclusion level of 5\% (Tacon and Cooke, 1980), although, as observed here, a negative effect on growth, feed intake and feed conversion was observed at the highest (10\%) dietary inclusion level. 
Similar observations were also made by Fournier et al. (2002). In that study, 2 incorporation of dietary RNA extract at levels of 3\% - 6\% in rainbow trout, or $4 \%-8 \%$ 3 in turbot, did not significantly affect growth rate, feed intake or feed efficiency. In 4 European sea bass similar levels of dietary RNA extract (6.2 and 12.4\%) were assayed 5 (Peres and Oliva-Teles, 2003) and results showed that incorporation of RNA extract to 6 the diets affected feed intake and feed efficiency, and significantly reduced growth rate 7 of fish fed the highest dietary RNA level. relatively lower levels (up to 4\%) as an immunostimulant (Li and Gatlin, 2003). Even at this low dietary incorporation level, enhanced weight gain and feed efficiency compared to the control diet was observed in hybrid striped bass (Li and Gatlin, 2003).

As regards nucleotides, beneficial effects of dietary supplementation is attributed to its effects as immunomodulators, particularly under stress conditions imposed by management or infectious diseases (Burrels et al. 2001a,b; Sakai et al., 2001; Li et al., 2004). Burrels et al. (2001a,b) found that inclusion of nucleotides at very low levels $(0.03 \%)$ besides increasing resistance to challenge infections, enhancing the efficacy of vaccination, and lowering mortality after challenge, also improved growth rate following salt water transfer.

were all isonitrogenous, nucleic acids appear to spare part of the dietary nitrogen for retention. In a similar comparative study with rainbow trout and turbot, Fournier et al. (2002) found no clear N sparing effect of dietary nucleic acids or brewers yeast supplementation in either species. Also in rainbow trout, Tacon and Cooke (1980) found no N sparing effect of nucleic cid supplemented diets. Rumsey et al. (1992) however, reported an incremental increase of $\mathrm{N}$ retention in rainbow trout fed increasing levels of dietary yeast extract, this data suggesting that some of the dietary nucleic acids and nonprotein $\mathrm{N}$ might be used for biosynthesis of nonessential amino acids.

In sea bass, Metailler and Huelvan (1993) also found no improvement in N retention in fish fed brewers yeast containing diets, although such effect was noticed with lactic and bakers yeast diets. On the contrary, Oliva-Teles and Gonçalves (2001), also in sea bass, found that $\mathrm{N}$ retention was significantly higher in fish fed brewers yeast containing diets. According to Metailler and Huelvan (1993) the improved protein 
1 retention in diets yeasts containing compared to the fish meal-based control diet might

2 be attributed to an increased biological value of the fish meal - yeast mixture as regard

3 to fish meal alone. Also in sea bass, the dietary supplementation of RNA had no protein

4 sparing effect (Peres and Oliva-Teles, 2003), in fact, $\mathrm{N}$ retention significantly decreased

5 in diets incorporating RNA extract.

6

\section{Body composition}

The lack of any significant difference in whole body composition is in agreement with observations from other similar studies on the use of brewers yeast or nucleic acid in fish (Takii et al., 1999; Peres and Oliva-Teles, 2003) except for the ash content of fish fed nucleic acid supplemented diets (Tacon and Cooke, 1980; Rumsey et al., 1992; Oliva-Teles and Gonçalves, 2001; Fournier et al., 2002). The relative changes in hepatosomatic indices in fish fed the RNA containing diets was also seen in other fish species (Peres and Oliva-Teles, 2003) as well as in rats (Novak et al., 1994), reflecting the important role liver plays in nucleotide metabolism regulation.

\section{Ammonia and urea excretion}

Ammonia excretion and total ammonia plus urea excretion increased with the dietary inclusion level of either brewers yeast or nucleic acids, being significantly higher in fish fed the RNA extract containing diets. As ammonia is an end product of pyrimidine catabolism, the increased ammonia excretion can be attributed to the catabolism of the additional intake of pyrimidine nucleotides in fish fed the experimental diets. In sea bass, $\mathrm{N}$ excretion in fish fed diets including ribonucleic acids follows a pattern similar to what was observed in this trial (Peres and Oliva-Teles, 2003). An increased ammonia excretion due to brewers yeast or nucleic acid intake was, however, not observed in rainbow trout or turbot (Fournier et al., 2002).

Daily urea nitrogen excretion increased as the amount of nucleic acid nitrogen intake increased, being particularly higher in fish fed diet RNA2. Urea excretion, as per cent of total ammonia plus urea excretion, was similar to that observed by Dosdat et al. (1996) except for groups fed FM and RNA2 diets. In teleosts urea is formed mainly through argininolysis and uricolysis due to degradation of purine nucleotides, as de novo synthesis by the ornithine-urea cycle pathway seems to be lacking in most adult fishes (Wood, 1993; Walsh, 1998; Anderson, 2001). Therefore, this increased daily urea excretion reflects an increased ureagenesis due to purine catabolism. This data 
1 corroborates that of Fournier et al. (2002), also showing a direct influence of dietary

2 purines on ureogenesis of teleosts.

\section{Plasma metabolites}

Plasma ammonia and urea levels six hours after feeding followed the same patterns as daily ammonia and urea excretion. Plasma ammonia levels observed in this trial were almost two-fold higher than values reported in the same species by Dosdat et al. (1996), while plasma urea levels in groups fed fish meal and brewers yeast diets were within the range of values measured by those authors.

According to Fournier et al. (2002) dietary nucleic acid nitrogen had no effect on plasma ammonia concentration in rainbow trout and turbot. As in this study, these authors also found a significantly higher plasma urea level six hours after the meal in fish fed the RNA supplemented diets as compared to the other groups. This increased post-prandial plasma urea levels also confirms the increased uricogenesis due to nucleic acid intake. Such an increase in plasma urea in rainbow trout fed high dietary nucleic acid inclusion levels was also observed by Tacon and Cooke (1980).

The absence of any significant change in GDH activity as observed here in fish fed the different diets has already been reported in gilthead sea bream, with no modification of GDH activity due to dietary protein sources (Gomez-Requini et al. 2004). This may reflect the absence of a clear adaptative response of amino acid deaminating enzymes to dietary protein levels, their activity remaining high even when protein intake is low (Cowey, 1995). Fournier et al. (2002) also did not find any differences in GDH activities in turbot fed RNA or brewer's yeast containing diets, although in rainbow trout, GDH activities decreased in fish fed the RNA based diets. Similarly, a reduction of GDH activity was also noticed in the present trial in fish fed RNA1 diet. In the red drum, McGoogan and Gatlin (1999) also found that GDH and other ammonia production enzymes were not responsive to dietary protein levels, although ammonia excretion was affected by increasing levels of protein. On the contrary, an adaptive behaviour due to different nutritional situations, namely prolonged starvation or feeding on a high protein diet was observed in rainbow trout by SanchezMuros et al. (1998). 
The lower activity of arginase in sea bream fed high dietary RNA can be 2 attributed to an arginine sparing effect caused by the lower arginine content of that diet. 3 Such a reduction in activity was also observed by Fournier et al. (2002) in turbot but, 4 surprisingly, not in rainbow trout. Also in rainbow trout, Chiu et al. (1986) found no significant differences in arginase or OTC activities due to starvation or dietary protein

6 levels when expressed per g protein or per g of fish, differences being evident only 7 when activities were expressed per g of liver. On the contrary, arginase activity was 8 higher in fish fed the brewers yeast diets than in the control. As brewers yeast contain 9 less arginine than fish meal an arginine sparing was also to be expected in fish fed brewers yeast diets, as was indeed observed by Fournier et al. (2002) both in turbot and rainbow trout.

Although OCT and other ornithine urea cycle enzymes only appear to function in arginine or urea synthesis via the urea cycle, low but significant levels of these enzymes have been reported in the liver of several teleost species (Felskie et al. (1998). In the present trial, OTC activity was very low in all groups, but was significantly higher in fish fed the RNA diets. According to Todgham et al. (2001), OTC activity in liver is very low, at least in rainbow trout, while it is much higher in muscle. These authors even proposed that if urea cycle is operative in rainbow trout, the first two steps (i.e. involving CPSIII and OTC) should occur in the muscle. Similar results to ours were also obtained by Fournier et al. (2002) in turbot, but not in rainbow trout. OTC activity levels observed by these authors in turbot were within the range of results we measured in sea bream, while values detected in rainbow trout were considerably lower. GouillouCoustans et al. (2002), in turbot, also observed a positive increase of arginase activity with increasing dietary arginine levels, while OTC activity remained very low. This led the foresaid authors to conclude that arginine degradation was de major pathway for ureagenesis in turbot while ornithine urea cycle was not active in the liver of this species.

Contrary to Tacon and Cooke (1980), who observed a significant increase in 29 liver uricase activity in fish fed diets high in nucleic acid, we did not observe any effect on uricase activity. In rainbow trout, Rumsey et al. (1991b) observed that liver uricase activity was directly related to dietary nucleic acid levels, and concluded that fish were not physiologically affected even by high dietary levels of nucleic acid nitrogen. As in our study, Fournier et al. (2002) also found no effect of dietary nucleic acids on uricase 
1 activity in turbot but, contrary to the above studies, observed a significant reduction of 2 activity in rainbow trout.

3

\section{CONCLUSION}

5

6 Results of this study show that inclusion of up to $23 \%$ of brewer's yeast or $6 \%$ 7 of RNA extract as fish meal substitutes on an equivalent $\mathrm{N}$ basis, improves growth 8 performance of gilthead sea bream. High levels of dietary RNA extract did not lead to 9 any further beneficial effect, but led top reduced performance.

10 Data on excretion, enzyme activities and plasma metabolites strongly suggest 11 that purinolysis contributes also to ureogenesis in gilthead sea bream.

\section{AKNOWLEDGEMENTS}

15

16 This work was partially supported by EU project FAIR CT 98-3408. 


\section{REFERENCES}

2

A.O.A.C., 1980. Official Methods of Analysis, $13^{\text {th }}$ ed. Association of Analytical Chemists, Washington, DC, 1018 p.

Alliot, E., Pastoureaud, A., Hudlet, J.P., Métailler, R., 1979. Utilisation des farines végétales et des levures cultivées sur alcanes pour l'alimentation du bar (Dicentrarchus labrax), In: Halver, J.E., Tiews, K. (Eds.), Finfish Nutrition and Fishfeed Technology. Heenemann. Berlin, pp. 229-238.

Anderson, D.P., 1992. Immunostimulants, adjuvants, and vaccine carriers in fish: applications to aquaculture. Annual Review of Diseases 21, 281-307.

Anderson, P.M., 2001. Urea and glutamine synthesis: Environmental influences on nitrogen excretion, Fish Physiology. Academic Press, pp. 239-277.

Anupama, Ravindra, P., 2000. Value-added food: single cell protein. Biotechnology Advances 18, 459-479.

Atack, T., Matty, A.J., 1979. The evaluation of some single-cell proteins in the diet of rainbow trout: II. The determination of net protein utilisation, biological values and true digestibility. In: Halver, J.E., Tiews, K. (Eds.), Finfish Nutrition and Fishfeed Technology. Heenemann. Berlin, pp. 261-273.

Beck, H., Gropp, J., Koops, H., Tiews, K., 1979. Single cell proteins in trout diets. In: Halver, J.E., Tiews, K. (Eds.), Finfish Nutrition and Fishfeed Technology. Heenemann, Berlin, pp. 269-280.

Bergmeyer, H.U., 1974. Methods of enzymatic analysis. Verlag Chimie. Vol. 4, 17041708.

Bergstrom, E., 1979. Experiments on the use of single cell proteins in Atlantic salmon diets. In: Halver, J.E., Tiews, K. (Eds.), Finfish Nutrition and Fishfeed Technology. Heenemann. Berlin, pp. 105-116.

Bradford, M.M., 1976. A rapid and sensitive method for the quantification of microgram quantities of protein utilizing the principle of protein-dye binding. Anaitical Biochemistry 72, 248-254. 
1 Burrells, C., Williams, P.D., Forno, P.F., 2001. Dietary nucleotides: a novel supplement in fish feeds 1. Effects on resistance to disease in salmonids. Aquaculture 199, 159-169.

Burrells, C., Williams, P.D., Southgate, P.J., Wadsworth, S.L., 2001. Dietary nucleotides: a novel supplement in fish feeds 2. Effects on vaccination, salt water transfer, growth rates and physiology of Atlantic salmon (Salmo salar L.). Aquaculture 199, 171-184.

Carver, J.D., 1999. Dietary nucleotides: effects on the immune and gastrointestinal systems. Acta Paediatrica 88, 83-88.

Carver, J.D., Walker, W.A., 1995. The role of nucleotides in human nutrition. Journal of Nutritional Biochemistry 6, 58-72.

Chiu, Y.N., Austic, R.E., Rumsey, G.L., 1986. Urea cycle activity and arginine formation in rainbow trout (Salmo gairdneri). Journal of Nutrition 116, 16401650.

Cleere, W.F., Bree, S., Coughlan, M.P., 1976. Urate Oxidase And Xanthine Dehydrogenase-Activities In Liver Extracts From Fish Caught In Irish Waters. Comparative Biochemistry and Physiology 54B, 117-119.

Cosgrove, M., 1998. Nucleotides. Nutrition 14, 748-751.

Cowey, C.B., 1995. Intermediary metabolism in fish with reference to output of end products of nitrogen and phosphorus. Water Science and Technology 31, 21-28.

de la Higuera, M., Sanchez-Muniz, F.J., Mataix, F.J., Varela, G., 1981. Nitrogen utilization by rainbow trout (Salmo gairdneri) fed on the yeast Hansenula anomala. Comparative Biochemistry and Physiology 69A, 583-586.

Dosdat, A., Servais, F., Metailler, R., Huelvan, C., Desbruyeres, E., 1996. Comparison of nitrogenous losses in five teleost fish species. Aquaculture 141, 107-127.

Felskie, A.K., Anderson, P.M., Wright, P.A., 1998. Expression and activity of carbamoyl phosphate synthetase III and ornithine urea cycle enzymes in various 
tissues of four fish species. Comparative Biochemistry and Physiology 119B, 355.

Fournier, V., Gouillou-Coustans, M.F., Metailler, R., Vachot, C., Moriceau, J., Le Delliou, H., Huelvan, C., Desbruyeres, E., Kaushik, S.J., 2002. Nitrogen utilisation and ureogenesis as affected by dietary nucleic acid in rainbow trout (Oncorhynchus mykiss) and turbot (Psetta maxima). Fish Physiology and Biochemistry 26, 177-188.

Gannam, A.L., Schrock, R.M., 1999. Immunostimulants in fish diets. Journal of Applied Aquaculture 9, 53-70.

Gatesoupe, F.J., 1999. The use of probiotics in aquaculture [Review]. Aquaculture 180, 147-165.

Gomez-Requeni, P., Mingarro, M., Calduch-Giner, J.A., Medale, F., Martin, S.A.M., Houlihan, D.F., Kaushik, S., Perez-Sanchez, J., 2004. Protein growth performance, amino acid utilisation and somatotropic axis responsiveness to fish meal replacement by plant protein sources in gilthead sea bream (Sparus aurata). Aquaculture 232, 493-510.

Gouillou Coustans, M.F., Fournier, V., Metailler, R., Vachot, C., Desbruyeres, E., Huelvan, C., Moriceau, J., Le Delliou, H., Kaushik, S.J., 2002. Dietary arginine degradation is a major pathway in ureagenesis in juvenile turbot (Psetta maxima). Comparative Biochemistry and Physiology 132A, 305-319.

Imafidon, G.I., Sosulski, F.W., 1990. Nucleic-acid nitrogen of animal and plant foods. Journal of Agricultural and Food Chemistry 38, 118-120.

Irianto, A., Austin, B., 2002. Probiotics in aquaculture. Journal of Fish Diseases 25, 633.

Kinsella, J.E., German, B., Shetty, J., 1985. Uricase from fish liver - isolation and some properties. Comparative Biochemistry and Physiology 82B, 621-624. 
1 Koroleff, F., 1983a. Determination of ammonia. In: Grasshoff, R., Ehrhardt, M., Kromling R., (Eds.), Methods of Seawater Analysis, 2nd edition, Verlag Chimic, Weimheim, Germany, pp. 150-162

Koroleff, F., 1983b. Determination of urea. In: Grasshoff, R., Ehrhardt, M., Kromling R., (Eds.), Methods of Seawater Analysis, 2nd edition, Verlag Chimic, Weimheim, Germany, pp. 158-162

Kubitza, F., Lovshin, L.L., Lovell, R.T., 1997. Identification of feed enhancers for juvenile largemouth bass Micropterus salmoides. Aquaculture 148, 2-3.

Li, P., Gatlin, D.M., 2003. Evaluation of brewers yeast (Saccharomyces cerevisiae) as a feed supplement for hybrid striped bass (Morone chrysops x M-saxatilis). Aquaculture 219, 681-692.

Li, P., Lewis, D.H., Gatlin, D.M., 2004. Dietary oligonucleotides from yeast RNA influence immune responses and resistance of hybrid striped bass (Morone chrysops $X$ Morone saxatilis) to Streptococcus iniae infection. Fish \& Shellfish Immunology 16, 561-569.

Low, C., Wadsworth, S., Burrells, C., Secombes, C.J., 2003. Expression of immune genes in turbot (Scophthalmus maximus) fed a nucleotide-supplemented diet. Aquaculture 221, 23-40.

Mahnken, C.V.W., Spinelli, J., Waknitz, F.W., 1980. Evaluation of an alkane yeast (Candida sp.) as a substitute for fish meal in oregon moist pellet: feeding trials with coho salmon (Oncorhynchs kisutch) and rainbow trout (Salmo gairdneri). Aquaculture, 20:41-56.

Matty, A.J., Smith, P., 1978. Evaluation of a yeast, a bacterium and an alga as a protein source for rainbow trout. I. Effect of protein level on growth, gross conversion efficiency and protein conversion efficiency. Aquaculture, 14:235-246.

McGoogan, B.B., Gatlin, D.M., 1999. Dietary manipulations affecting growth and nitrogenous waste production of red drum, Sciaenops ocellatus I. Effects of dietary protein and energy levels. Aquaculture 178, 333-348. 
1 Metailler, R., Huelvan, C., 1993. Utilisation de levures dans l'alimentation du juvenile de bar (Dicentrarchus labrax). In: Fish Nutrition in Practice. Ed. INRA, Les Colloques 61, 945-948.

Murray, A.P., Marchant, R., 1986. Nitrogen utilization in rainbow trout fingerlings (Salmo gairdneri Richardson) fed mixed microbial biomass. Aquaculture 54, 263-275.

Nose, T., 1974. Effects of amino acids supplemented to petroleum yeast on growth of rainbow trout fingerlings - I. A preliminary experiment. Bulletin of the Freshwater Fisheries Research Laboratory 24, 57-63.

Novak, D.A., Carver, J.D., Barness, L.A., 1994. Dietary nucleotides affect hepatic growth and composition in the weanling mouse. Journal of Parenter. Enteral Nutrition 18, 62- 66.

Oliva-Teles, A., Goncalves, P., 2001. Partial replacement of fishmeal by brewers yeast (Saccaromyces cerevisae) in diets for sea bass (Dicentrarchus labrax) juveniles. Aquaculture 202, 269-278.

Olvera-Novoa, M.A., Martinez-Palacios, C.A., Olivera-Castillo, L., 2002. Utilization of torula yeast (Candida utilis) as a protein source in diets for tilapia (Oreochromis mossambicus Peters) fry. Aquaculture Nutrition 8, 257-264.

Peres, H., Oliva-Teles, A., 2003. The effect of dietary ribonucleic acid incorporation in performance of European sea bass (Dicentrarchus labrax) juveniles. Aquaculture 215, 245-253.

Porter, C.B., Krom, M.D., Robbins, M.G., Brickell, L., Davidson, A., 1987. Ammonia excretion and total $\mathrm{N}$ budget for gilthead seabream (Sparus aurata) and its effect on water quality conditions. Aquaculture 66, 287-297.

Rumsey, G.L., Hughes, S.G., Kinsella, J.L., 1990. Use of dietary yeast Saccharomyces cerevisiae nitrogen by lake trout. JOurnal of the World Aquaculture Society. 21, 205-209. 
1 Rumsey, G.L., Winfree, R.A., Hughes, S.G., 1992. Nutritional value of dietary nucleic acids and purine bases to rainbow trout (Oncorhynchus mykiss). Aquaculture 108, 97-110.

Rumsey, G.L., Kinsella, J.E., Shetty, K.J., Hughes, S.G., 1991. Effect of high dietary concentrations of brewer's dried yeast on growth performance and liver uricase in raibow trout (Oncorhynchus mykiss). Animal Feed Science and Technology 33, 177-183.

Rumsey, G.L., Hughes, S.G., Smith, R.R., Kinsella, J.E., Shetty, K.J., 1991. Digestibility and energy values of intact, disrupted and extracts from brewer's dried yeast fed to rainbow trout. Animal Feed Science and Technology 33, 185193.

Sakai, M., 1999. Current research status of fish immunostimulants [Review]. Aquaculture 172, 63-92.

Sakai, M., Taniguchi, K., Mamoto, K., Ogawa, H., Tabata, M., 2001. Immunostimulant effects of nucleotide isolated from yeast RNA on carp, Cyprinus carpio L. Journal of Fish Diseases 24, 433-438.

Sanchez-Muros, M.J., Garcia-Rejon, L., Garcia-Salguero, L., de laHiguera, M., Lupianez, J.A., 1998. Long-term nutritional effects on the primary liver and kidney metabolism in rainbow trout. Adaptive response to starvation and a highprotein, carbohydrate-free diet on glutamate dehydrogenase and alanine aminotransferase kinetics. International Journal of Biochemistry \& Cell Biology 30, 55-63.

Schulz, E., Oslage, H.J., 1976. Composition and nutritive value of single-cell protein (SCP). Animal Feed Science and Technology, 9-24.

Spinelli, J., Mahnken, C., Steinberg, M., 1979. Alternate sources of proteins for fish meal in salmonid diets. In: Halver, J.E., Tiews, K. (Eds.), Finfish Nutrition and Fishfeed Technology. Heenemann. Berlin Vol.II p.131-142.

Tacon, A.G.J., Cooke, D.J., 1980. Nutritional value of dietary nucleic acids to trout. Nutrition Reports International 22, 631- 640. 
1 Tacon,A.G.J., Jackson, A.J., 1985. Utilisation of conventional and unconventional

2

3

4 Tacon, A.G.J., 1994. Feed ingredients for carnivorous fish species: Alternatives to 5 protein sources in practical fish feeds. In: Nutrition and Feeding in Fish. Academic Press., p.119-145.

fishmeal and other dietary resources. FAO Fisheries Circular n ${ }^{\circ}$ 881, 35p.

Takii, K., Maoka, T., Seoka, M., Kondo, T., Nakamura, M., Kitano, H., Kumai, H., 1999. Preliminary assessment of dietary yeast, Saccharomyces cerevisiae, protein for red sea bream. Suisanzoshoku 47, 71-76.

Walsh, P.J., 1998. Nitrogen excretion and metabolism. In: Evans, D.H. (Ed.), The 0 Physiology of Fishes. CRC Press, N.Y., pp. 199-214.

Watanabe, T., 2002. Strategies for further development of aquatic feeds. Fisheries 12 Science 68, 242-252.

3 Wood, C.M., 1993. Ammonia and urea metabolism and excretion. In: Evans, D.H. 4 (Ed.), The Physiology of Fishes. CRC Press, Boca Raton, pp. 379-425. 
4

\begin{tabular}{lccccc}
\hline Diets & FM & BY1 & BY2 & RNA1 & RNA2 \\
\hline Ingredients(\%) & & & & & \\
Fish meal & 50.5 & 44.3 & 38.2 & 44.4 & 38.3 \\
Fish soluble protein concentrate & 5.0 & 5.0 & 5.0 & 5.0 & 5.0 \\
Extruded wheat & 37.8 & 31.7 & 25.5 & 37.5 & 37.2 \\
Fish oil & 4.7 & 5.5 & 6.3 & 5.4 & 6.0 \\
RNA extract & 0.0 & 0.0 & 0.0 & 5.8 & 11.5 \\
Brewer's yeast & 0.0 & 11.5 & 23.0 & 0.0 & 0.0 \\
Vitamin mixture $^{1}$ & 1 & 1 & 1 & 1 & 1 \\
Mineral mixture $^{1}$ & 1 & 1 & 1 & 1 & 1
\end{tabular}

Proximate analysis

Moisture (\%)

$\begin{array}{lllll}7.0 & 7.4 & 8.6 & 6.7 & 7.6\end{array}$

$\mathrm{N} \times 6.25(\%)$

$\begin{array}{lllll}43.5 & 43.7 & 44.9 & 43.6 & 44.4\end{array}$

Ether extract (\%)

$\begin{array}{lllll}10.3 & 10.3 & 10.2 & 10.7 & 10.9\end{array}$

Ash (\%)

$\begin{array}{lllll}8.4 & 8.2 & 8.0 & 8.0 & 8.4\end{array}$

$\mathrm{NAN}^{2}(\%)$

$\begin{array}{llll}0.084 & 0.09 & 0.10 & 0.22\end{array}$

0.30

${ }^{2}$ Nucleic Acid Nitrogen 
2 Table 2. Growth and feed utilization of sea bream juveniles fed the experimental diets ${ }^{1}$ 3

\begin{tabular}{lcccccc}
\hline \multicolumn{1}{c}{ Diet: } & FM & BY1 & BY2 & RNA1 & RNA2 & SEpooled \\
\hline Initial mean weight (g) & 12.7 & 12.7 & 12.7 & 12.7 & 12.7 & 0.003 \\
Final mean weight (g) & $43.6 \mathrm{a}$ & $48.7 \mathrm{bc}$ & $49.4 \mathrm{bc}$ & $52.0 \mathrm{c}$ & $46.3 \mathrm{ab}$ & 1.06 \\
Weight gain (g/kg/day) & $15.7 \mathrm{a}$ & $16.8 \mathrm{ab}$ & $16.9 \mathrm{~b}$ & $17.3 \mathrm{~b}$ & $16.3 \mathrm{ab}$ & 0.23 \\
SGR $^{2}$ (\%) & $1.76 \mathrm{a}$ & $1.92 \mathrm{bc}$ & $1.94 \mathrm{bc}$ & $2.02 \mathrm{c}$ & $1.84 \mathrm{ab}$ & 0.03 \\
Feed intake (g/kg/day) & $17.3 \mathrm{a}$ & $18.7 \mathrm{~b}$ & $18.7 \mathrm{~b}$ & $19.2 \mathrm{~b}$ & $18 \mathrm{ab}$ & 0.28 \\
Feed efficiency & 0.91 & 0.90 & 0.90 & 0.90 & 0.90 & 0.003 \\
Protein efficiency & & & & & & \\
N gain (g/kg ABW/day) & 0.392 & 0.434 & 0.412 & 0.454 & 0.420 & 0.014 \\
N retention (\% Nitrogen Intake) & 36.8 & 35.6 & 32.8 & 36.6 & 36.0 & 0.97 \\
Mortality (\%) & 0.68 & 0 & 0.68 & 0.68 & 0 & 0.53 \\
\hline
\end{tabular}

$4{ }^{1}$ In the same row, numbers followed by different letters are significantly different $5 \quad(\mathrm{p}<0.05)$

$6 \quad{ }^{2}$ Specific growth rate: (ln final weight - ln initial weight)/time in days

$7 \quad{ }^{3}$ Feed efficiency: wet weight gain: dry feed intake

$8{ }^{4}$ Protein efficiency: wet weight gain: protein intake

9 ABW: average body weight

10 
1 Table 3. Body composition (expressed as \% wet weight) and hepatosomatic index (HSI)

2 of sea bream juveniles fed the experimental diets ${ }^{1}$

\begin{tabular}{cccccccc}
\hline Diet: & Start & FM & Y1 & Y2 & RNA1 & RNA2 & SEpooled \\
& & & & & & & \\
\hline Water content & 70.6 & 69.9 & 68.5 & 68.0 & 69.1 & 69.0 & 0.66 \\
Protein & 14.2 & 15.2 & 15.7 & 14.9 & 15.8 & 15.6 & 0.32 \\
Lipids & 10.2 & $10.2 \mathrm{ab}$ & $10.0 \mathrm{a}$ & $11.4 \mathrm{~b}$ & $9.6 \mathrm{a}$ & $9.9 \mathrm{a}$ & 0.30 \\
Ash & 4.0 & 4.5 & 4.2 & 4.1 & 4.5 & 4.4 & 0.09 \\
HSI & & 2.28 & 2.29 & 2.3 & 2.57 & 2.55 & 0.12
\end{tabular}

$3{ }^{1}$ In the same row, numbers followed by different letters are significantly different $4 \quad(\mathrm{p}<0.05)$

5 
1 Table 4. Hepatic enzyme activities and plasma ammonia and urea levels in sea bream 2 juveniles fed the experimental diets ${ }^{1}$

3

\begin{tabular}{llllll}
\hline FM & Y1 & Y2 & RNA1 & RNA2 SEpooled
\end{tabular}

\begin{tabular}{lcccccc}
\hline \multicolumn{1}{c}{ Enzyme activities } & & & & & & \\
GDH (IU-3) & $255.8 \mathrm{bc}$ & $247.6 \mathrm{~b}$ & $220.2 \mathrm{a}$ & $209.9 \mathrm{a}$ & $263.5 \mathrm{c}$ & 5.43 \\
ARG (IU) & $1722.4 \mathrm{~b}$ & $2047.4 \mathrm{c}$ & $2041.9 \mathrm{c}$ & $1737.6 \mathrm{~b}$ & $1161.1 \mathrm{a}$ & 48.20 \\
OTC (IU) & $5.85 \mathrm{a}$ & $10.33 \mathrm{~d}$ & $6.44 \mathrm{a}$ & $7.71 \mathrm{~b}$ & $9.04 \mathrm{c}$ & 0.31 \\
Uricase $(\mu \mathrm{mol})$ & 23.5 & 18.8 & 23.6 & 21.2 & 19.6 & 1.59
\end{tabular}

Plasma catabolites

$\begin{array}{lllllll}\text { N.NH4 (mg/l) } & 10.8 \mathrm{~b} & 9.8 \mathrm{a} & 10.6 \mathrm{~b} & 10.3 \mathrm{ab} & 11.8 \mathrm{c} & 0.18 \\ \text { N.Urea (mg/l) } & 40.4 \mathrm{a} & 39.0 \mathrm{a} & 39.4 \mathrm{a} & 65.0 \mathrm{~b} & 75.4 \mathrm{c} & 1.17\end{array}$

$4{ }^{1}$ In the same row, numbers followed by different letters are significantly different $5 \quad(\mathrm{p}<0.05)$ 
2 Table 5. Ammonia and urea excretion of sea bream juveniles fed the experimental diets ${ }^{1}$ 3

\begin{tabular}{ccccccc}
\hline & FM & Y1 & Y2 & RNA1 & RNA2 & SEpooled \\
\hline $\mathbf{n}$ & 6 & 6 & 6 & 6 & 6
\end{tabular}

Ammonia excretion

mg N.NH4/kg/day $\quad$ 536.0a $\quad 603.4 \mathrm{a} \quad 688.5 \mathrm{ab} \quad 838.9 \mathrm{~b} \quad 793.4 \mathrm{~b} \quad 44.4$

mg N.NH4/100g feed intake $\quad$ 2829.5a 3332.8ab 3553.3b 4436.8c4680.7c 146.9

Urea excretion

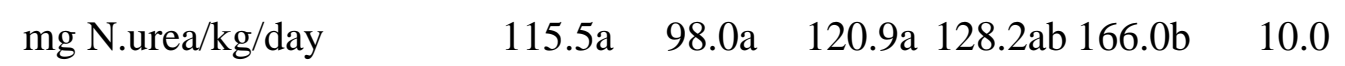

mg N.urea /100g feed intake $\quad 614.6 \mathrm{a} \quad 539.0 \mathrm{a} \quad$ 628.6a $\quad 680.0 \mathrm{a} \quad 976.6 \mathrm{~b} \quad 44.4$

$\begin{array}{lllllll}\% & \text { N.NH4 + Urea } \quad 18.0 b & 13.9 \mathrm{a} & 14.9 \mathrm{ab} & 13.4 \mathrm{a} & 17.2 \mathrm{~b} & 0.77\end{array}$

Total (Ammonia + Urea)N excretion

mg N.NH4/kg/day $\quad$ 651.5a $\quad 701.4 a \quad 809.4 a b ~ 967.1 b \quad 959.3 b \quad 51.6$

$4{ }^{1}$ In the same row, numbers followed by different letters are significantly different

$5 \quad(\mathrm{p}<0.05)$

6

7

8 